\title{
Eagle syndrome masquerading as a chicken bone
}

\author{
Jason E. Cohn ${ }^{1 *}$ D, Sammy Othman ${ }^{2}$ and Karima Sajadi-Ernazarova ${ }^{3}$
}

\begin{abstract}
This is a brief report of a 17-year-old male who presented to the emergency department with odynophagia and a foreign body sensation in the throat after choking on a chicken wing. A soft tissue neck radiograph was performed which revealed a 4.6- $\mathrm{cm}$ linear object in the vallecula read by the radiology department as a chicken bone. The otolaryngology team was consulted and performed a nasopharyngeal laryngoscopy which did not reveal a foreign body in the upper aerodigestive tract. On physical examination, the right tonsillar fossa was tender to palpation. Upon further review of the radiograph, the right stylohyoid ligament was noted to be elongated and calcified. Thereafter, the diagnosis of Eagle syndrome was made. This case provides an important teaching point for providers by pointing out a syndrome that can mimic other disease processes. In addition, it emphasizes the importance of providers reviewing their own films.
\end{abstract}

Keywords: Eagle syndrome, Elongated stylohyoid ligament, Calcified stylohyoid ligament, Chicken bone, Plain radiograph

\section{Case presentation}

A 17-year-old male presented to the emergency department with odynophagia and a foreign body sensation in the throat after choking on a chicken wing. A soft tissue neck radiograph was performed which revealed a $4.6-\mathrm{cm}$ linear object in the vallecula read by the radiology department as a chicken bone. The otolaryngology team was consulted and performed a nasopharyngeal laryngoscopy which was unremarkable. On physical examination, the right tonsillar fossa was tender to palpation. Upon further review of the radiograph, the right stylohyoid ligament was noted to be elongated and calcified (Fig. 1).

\section{Diagnosis}

\section{Eagle syndrome}

Although this patient presented after choking on a chicken bone, there was no foreign body present in the aerodigestive tract. The key symptom of foreign body sensation can be a classic presentation of Eagle syndrome.

Eagle syndrome is a symptomatic elongation with either overgrowth of the styloid process itself or ossification of the stylohyoid ligament complex [1]. Symptoms can include a constant dull pharyngeal pain, focused in the ipsilateral tonsillar fossa, that can be referred to the ear and aggravated by rotation of the head as well as the sensation of a foreign body in the pharynx, dysphagia, odynophagia, headache, and tinnitus [1,2].

* Correspondence: jasoncoh@pcom.edu

${ }^{1}$ Department of Otolaryngology-Head and Neck Surgery, Philadelphia

College of Osteopathic Medicine, 4190 City Line Avenue, Philadelphia, PA

19131, USA

Full list of author information is available at the end of the article

(C) The Author(s). 2020 Open Access This article is distributed under the terms of the Creative Commons Attribution 4.0 International License (http://creativecommons.org/licenses/by/4.0/), which permits unrestricted use, distribution, and reproduction in any medium, provided you give appropriate credit to the original author(s) and the source, provide a link to the Creative Commons license, and indicate if changes were made. 


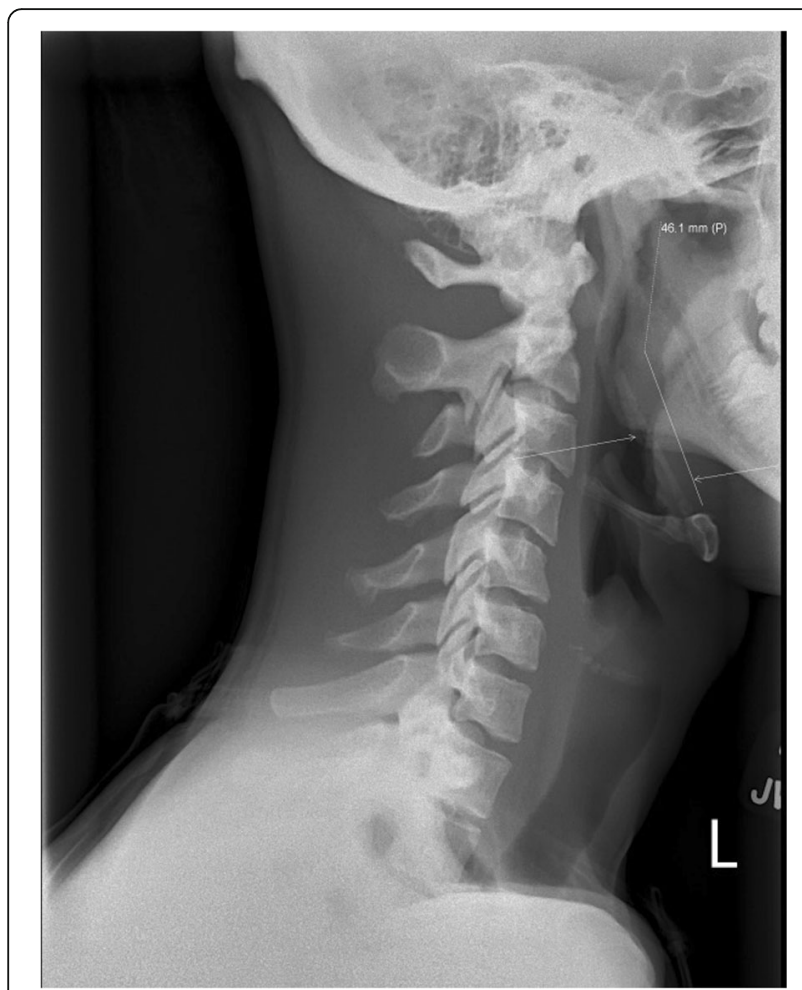

Fig. 1 Elongated and calcified stylohyoid ligament on lateral neck radiograph (arrow) measuring $4.6 \mathrm{~cm}$

The diagnosis can be made on plain radiograph, but CT is the most accurate [1-3]. The normal length of the adult styloid is approximately $2.5 \mathrm{~cm}$ while greater than $3 \mathrm{~cm}$ is considered elongated [1]. Treatment options include medical therapies (typically analgesics) and transoral or external surgeries (i.e., styloidectomy) $[1,2]$.

\section{Acknowledgements}

Not applicable

\section{Authors' contributions}

All authors read and approved the final manuscript.

\section{Funding}

None

Availability of data and materials

Not applicable

Ethics approval and consent to participate

Not applicable

\section{Consent for publication}

Not applicable

\section{Competing interests}

The authors declare that they have no competing interests.

\section{Author details}

'Department of Otolaryngology-Head and Neck Surgery, Philadelphia College of Osteopathic Medicine, 4190 City Line Avenue, Philadelphia, PA 19131, USA. ${ }^{2}$ Department of Emergency Medicine, Drexel University College of Medicine, Philadelphia, PA, USA. ${ }^{3}$ Drexel University College of Medicine, Philadelphia, PA, USA.
Received: 19 December 2019 Accepted: 3 January 2020

Published online: 13 January 2020

\section{References}

1. Bokhari MR, Mohseni M. Eagle syndrome. StatPearls [Internet]. Treasure Island (FL): StatPearls Publishing; 2018.

2. Badhey A, Jategaonkar A, Anglin Kovacs AJ, et al. Eagle syndrome: a comprehensive review. Clin Neurol Neurosurg. 2017 Aug;159:34-38. doi: https://doi.org/10.1016/j.clineuro.2017.04.021. Epub 2017 May 6.

3. Murtagh RD, Caracciolo JT, Fernandez G. CT findings associated with Eagle syndrome. AJNR Am J Neuroradiol. 2001 Aug;22(7):1401-2.

\section{Publisher's Note}

Springer Nature remains neutral with regard to jurisdictional claims in published maps and institutional affiliations.
Ready to submit your research? Choose BMC and benefit from:

- fast, convenient online submission

- thorough peer review by experienced researchers in your field

- rapid publication on acceptance

- support for research data, including large and complex data types

- gold Open Access which fosters wider collaboration and increased citations

- maximum visibility for your research: over $100 \mathrm{M}$ website views per year

At BMC, research is always in progress.

Learn more biomedcentral.com/submissions 